\title{
A Review on Maintenance and Troubleshooting of DC Machines
}

\author{
K. Mahesh Kumar \\ Department of EEE
}

Sethu Institute of Technology,

Pulloor, Kariapatti, India

\author{
A.Krishnaveni \\ Department of ECE \\ P.S.R Engineering College, \\ Sivakasi, India \\ T. Gunasekaran \\ P.Manikandan \\ Lieutenant. J.Ganesan \\ Department of EEE \\ Sree Sowdambika College of \\ Engineering, Aruppukottai, \\ India
}

\author{
D. Edison Selvaraj \\ Department of EEE \\ Panimalar Engineering College \\ Chennai, India
}

\begin{abstract}
This paper simply covers the maintenance of DC machines. In addition DC Generator, DC Motor types and applications are discussed neatly. DC motor troubles and their remedies are listed in simple figure. This paper would be helpful for the technicians to improve the plant efficiency.
\end{abstract}

Keywords: Motor, Generator, Commutator, armature, brush

\section{INTRODUCTION}

An electrical machine is a device which converts mechanical energy into electrical energy or vice versa. Now a day's dc motor plays important role in electric traction and industry. In industry routine maintenance is essential to reducing plant downtime.

\section{TYPES OF DC MACHINES}

DC machines classified in to two types DC Generator and DC Motor.

\subsection{Generator}

An Electrical generator is a rotating machine which converts mechanical energy into electrical energy. This energy conversion is based on the principle of electromagnetic induction. According to Faraday's laws of electromagnetic induction, whenever a conductor is moved in a magnetic field, dynamically induced e.m.f is produced in the conductor.

\subsubsection{Types of DC Generator}

DC generators can be classified according to their methods of excitation. There are two types of DC generators [4].

\section{Separately excited DC generator}

2. Self excited DC generator

$\begin{array}{ll}\text { i. } & \text { Series generator } \\ \text { ii. } & \text { Shunt generator } \\ \text { iii. } & \text { Compound generator } \\ & \text { a. Long shunt Compound generator } \\ & \text { b. Short shunt Compound generator }\end{array}$

\subsubsection{Applications of DC Generator}

\begin{tabular}{|c|c|c|}
\hline $\begin{array}{l}\text { S. } \\
\text { No. }\end{array}$ & $\begin{array}{c}\text { Type of } \\
\text { Generator }\end{array}$ & Applications \\
\hline 1 & $\begin{array}{l}\text { DC shunt } \\
\text { Generator }\end{array}$ & $\begin{array}{l}\text { For electro plating } \\
\text { Battery charging } \\
\text { For excitation of Alternators }\end{array}$ \\
\hline 2 & $\begin{array}{l}\text { Series } \\
\text { Generators }\end{array}$ & $\begin{array}{l}\text { Used as Boosters } \\
\text { Used for supply to arc Lamps }\end{array}$ \\
\hline \multirow{3}{*}{3} & \multirow{3}{*}{$\begin{array}{l}\text { Compound } \\
\text { Generator }\end{array}$} & $\begin{array}{l}\text { Differential Compound } \\
\text { generators are used to supply dc } \\
\text { welding machines. }\end{array}$ \\
\hline & & $\begin{array}{l}\text { Level compound generators are } \\
\text { used to supply power for offices, } \\
\text { hostels and Lodges etc. }\end{array}$ \\
\hline & & $\begin{array}{l}\text { Over compound generators are } \\
\text { used to compensate the voltage } \\
\text { drop in Feeders }\end{array}$ \\
\hline 4 & $\begin{array}{l}\text { Separately } \\
\text { Exited } \\
\text { Generator }\end{array}$ & $\begin{array}{l}\text { As a supply source to DC } \\
\text { Motors, whose speed is to be } \\
\text { controlled for certain } \\
\text { applications. } \\
\text { Where a wide range of voltage is } \\
\text { required for the testing purposes }\end{array}$ \\
\hline
\end{tabular}

The table 1 shows the applications of DC generator. 


\subsection{Motor}

\subsubsection{Basic Principle of DC motor}

The basic principle of operation of a dc motor is a whenever a current carrying conductor is placed in a magnetic field, the conductor experiences a force tending to move it [4].

\subsubsection{Types of DC motor}

The classification of DC motors is based on the connections of filed winding in relation to the armature

1. Separately excited DC motor

2. Self excited DC motor

a. Series motor

b. Shunt motor

c. Compound motor

- Long shunt compound motor

- Short shunt compound motor

2.2.3 Applications of DC Motors

The table 2 shows the applications of DC motor.

The Table 2 Applications of DC motor

\begin{tabular}{|c|c|c|}
\hline $\begin{array}{l}\text { S. } \\
\text { No. }\end{array}$ & Type of Motor & Applications \\
\hline 1 & DC Shunt Motor & $\begin{array}{l}\text { Blowers } \\
\text { Fans } \\
\text { Centrifugal and Reciprocating } \\
\text { pump } \\
\text { Lathe machines } \\
\text { Machine tools } \\
\text { Milling Machines } \\
\text { Drilling Machines }\end{array}$ \\
\hline 2 & DC Series Motor & $\begin{array}{l}\text { Cranes } \\
\text { Hoists } \\
\text { Elevators } \\
\text { Trolleys } \\
\text { Conveyors } \\
\text { Electric Locomotives }\end{array}$ \\
\hline 3 & $\begin{array}{l}\text { Cumulative } \\
\text { Compound Motor }\end{array}$ & $\begin{array}{l}\text { Rolling mills } \\
\text { Punches } \\
\text { Shears } \\
\text { Heavy planers } \\
\text { Elevators }\end{array}$ \\
\hline 4 & $\begin{array}{l}\text { Differential } \\
\text { Compound Motor }\end{array}$ & $\begin{array}{l}\text { Not suitable for practical } \\
\text { applications }\end{array}$ \\
\hline
\end{tabular}

\section{PROCEDURE FOR STARTING OF DC GENERATOR}

The following figure 1 shows the procedure for starting of DC generator.

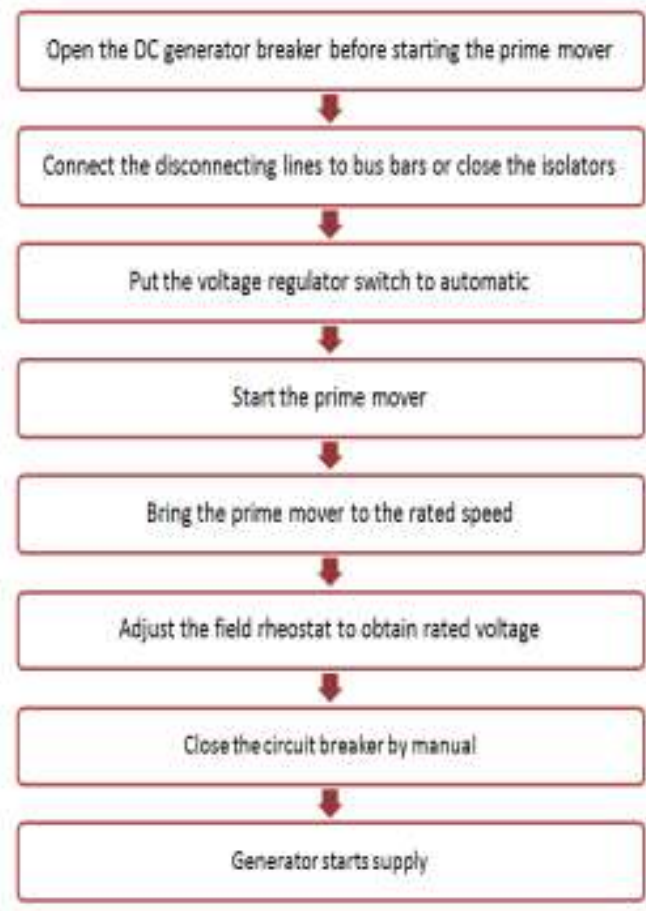

Figure 1 Procedure for Starting of DC Generator

\section{CAUSES OF VOLTAGE FAILURE OF DC GENERATOR}

Voltage failure is mainly caused by failure to build up the flux and low speed. The following figure 2 shows the various causes of voltage failure of DC Generator [1].

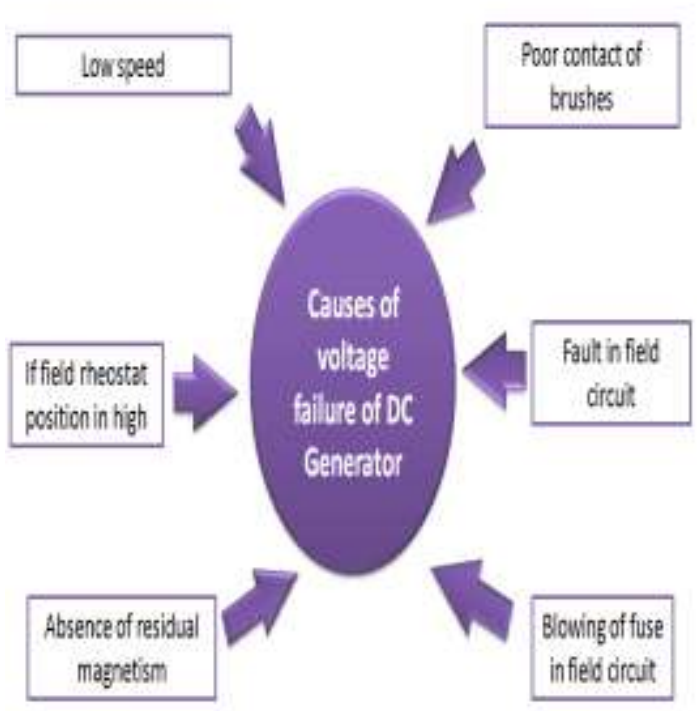

Figure 2 various causes of voltage failure of DC Generator 


\section{PROCEDURE OF INSTALLATION AND COMMISSIONING OF DC MOTOR}

The following figure 3 shows the Procedure of installation and commissioning of DC Motor

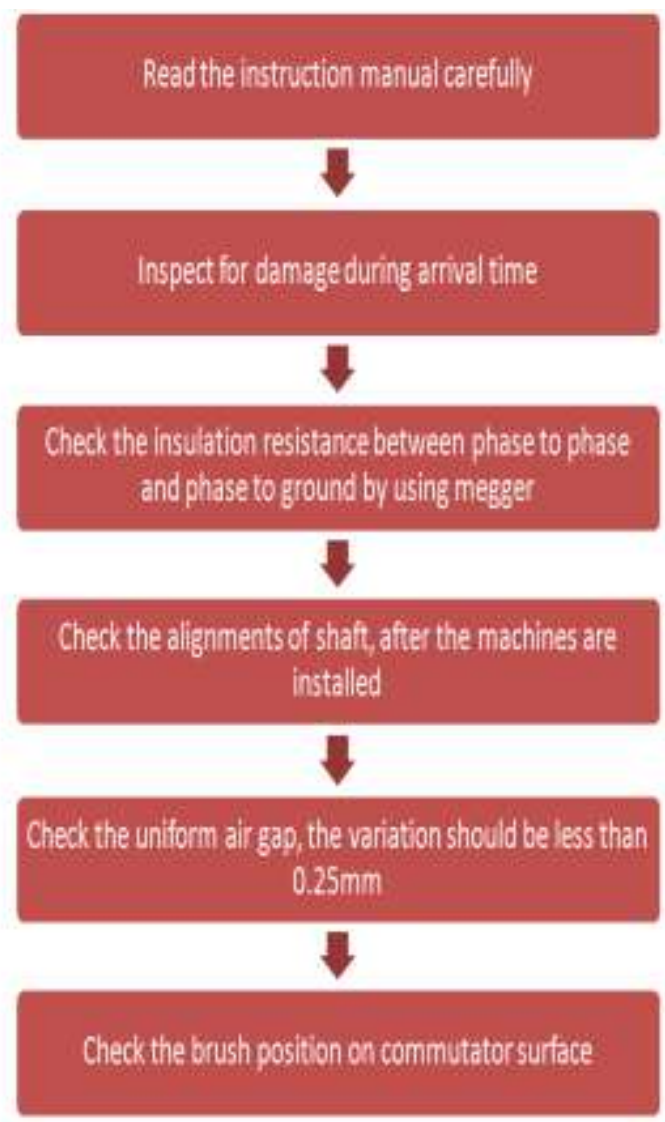

Figure 3 Procedure of installation and commissioning of DC Motor

The following figure 4 shows the Primary check during installation of DC Motor

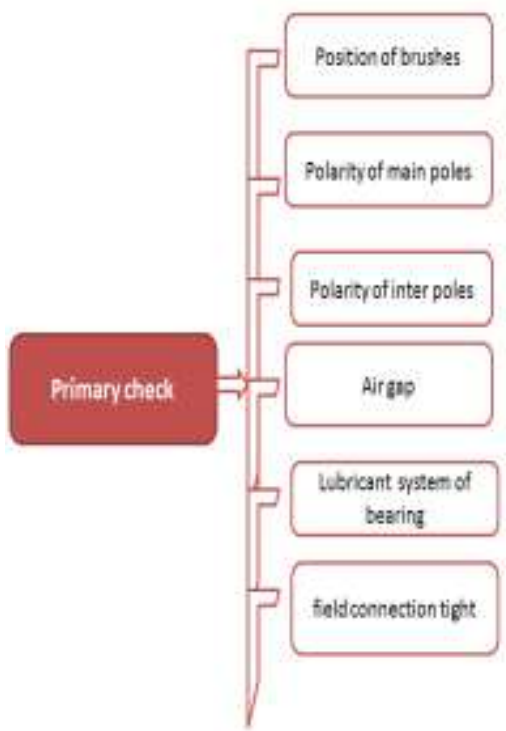

Figure 4 Primary checks during installation of DC Motor www.ijsea.com
The following figure 5 shows the Running checks after installation of DC Motor

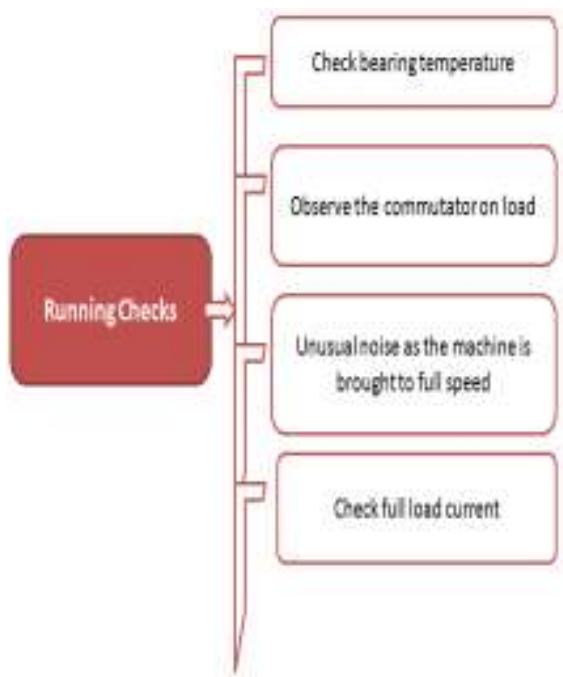

Figure 5 Running checks after installation of DC Motor

\section{PREVENTIVE MAINTENANCE}

\subsection{Preventive maintenance}

1. Includes electrical testing and visual inspection of the armature, commutator, brushes and filed coils [2]

2. Insulation to ground tests on DC equipment to evaluate the condition of insulation.

3. Checking brushes and commutator condition are very important parts of preventive maintenance

\subsection{Armature}

1. Visual inspection of the armature should include the search for cracked or brittle insulation, loose or broken banding and any dirt or oil contamination.

2. Leakage to ground testing of the armature indicates the insulation condition.

3. Bar to bar resistance check indicates shorted winding or defective solder joints at the risers.

4. Infrared inspection of the armature can reveal overheating of the brushes, commutator, loose or hot connections on the risers [3].

6.3 Fields

1. Visual inspection of the filed coils will expose cracked or brittle insulation.

2. Leakage testing provides the insulation level.

3. Drop test are used to find out shorted winding. In this test $110 \mathrm{v}$ ac is applied to the field leads. The voltage drop across each filed pole is measured with a voltmeter. In healthy motor, all voltage drops should be equal.

\subsection{Commutator}

Check the commutator surface, brush and brush holder tension.

\subsubsection{High Mica}

1. Mica is the insulation material used between each segment in a commutator.

2. Mica should be approximately $1 / 16 "$ lower than the adjacent commutator bars 
3. If the commutator bars are worn the result will be brush chatter. Putting the dumb end of a lead pencil or other insulated device, on a brush while the motor is rotating and feeling for vibration can identify this.

6.4.2 High Commutator bars

Usually caused by the wedge or wedge ring [3].

\section{DEFECTS IN ARMATURE WINDING, COMMUTATOR}

The following types of faults occurred in armature winding. They are Open circuit fault, Short circuit fault and Earth fault or ground fault [5]

\subsection{Open circuit fault:}

Occurs when the armature conductors get broken or when a joint with commutator pulls out.

\subsection{Short circuit fault}

If the insulation between armature conductors in failure, a current floes between them. This is called short circuit.

\subsection{Earth fault:}

Due to failure of insulation of armature conductor and slot insulation a faulty current flows from armature conductor to core. This fault is called earth fault [6].

\subsection{Causes of sparking in commutator}

Sparking is the production of an arc due to jumping of current occurs due to the following reasons

\section{Overloading}

2. Brushes may be sticking in the holders.

3. Spring pressure may not be sufficient.

4. Brushes may be burned on the edges.

5. Commutator surface may be rough having high bars.

6. Grade of carbon brushes may be incorrect.

7. Mica may be high in the slots. Brushes will wear act rapidly with high mica.

8. Pressure on some brushes may be more, resulting in sparking.

9. Brushes may be too loose in the holders.

10. Pig tails may be loose in the same of the brushes.

11. Sparking can also be due to defects in the armature and field circuits.

12. If there is an open circuit in the commutator riser, a bright flying spark will occur.

\section{TROUBLE SHOOTING}

The following figure 6 to 10 shows the different type of DC Motor troubles and their remedies [5].

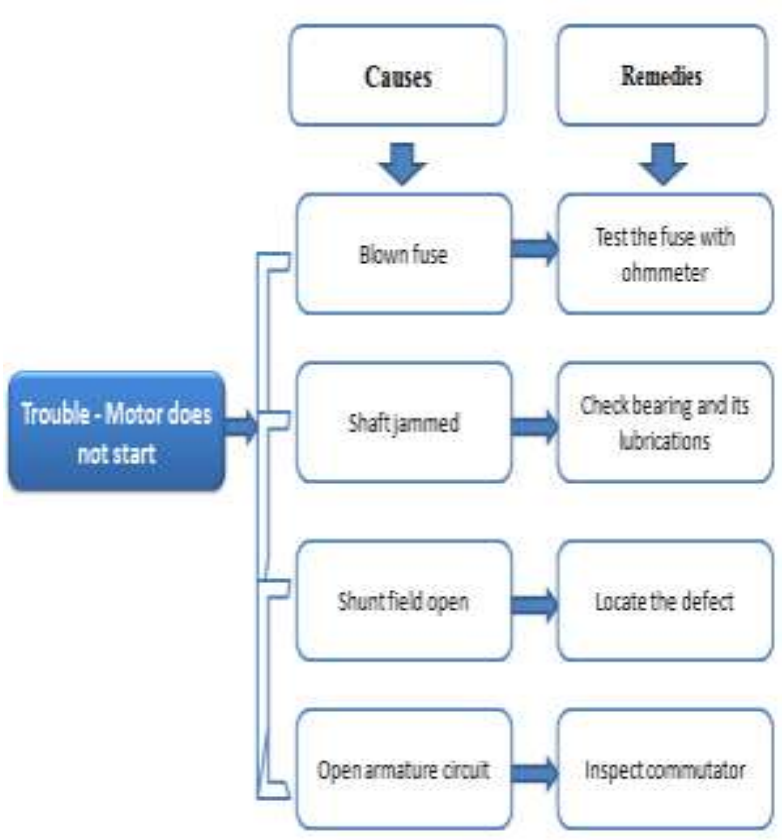

Figure 6 Motor does not start trouble and their remedies

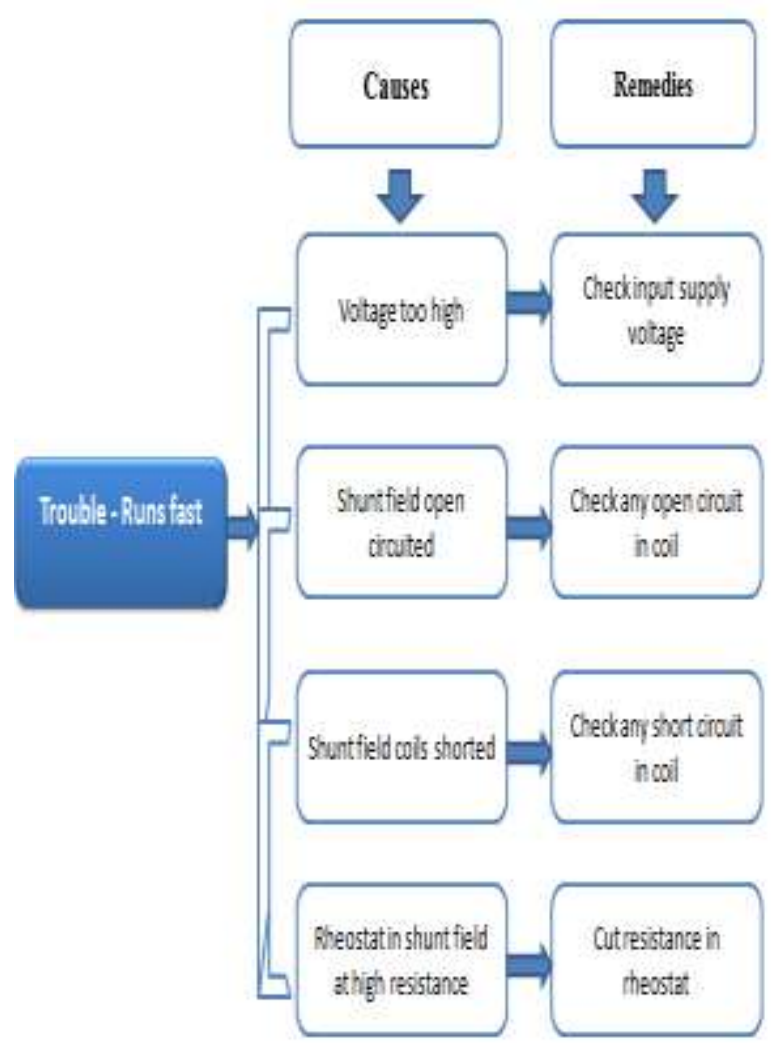

Figure 7 Motor runs fast trouble and their remedies 


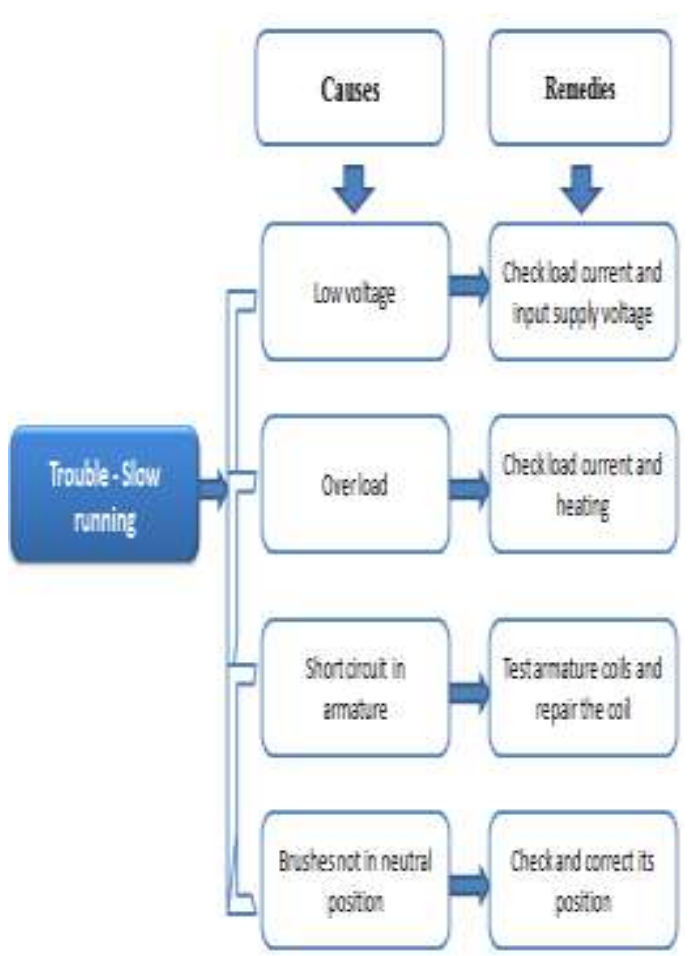

Figure 8 Motor slow running trouble and their remedies

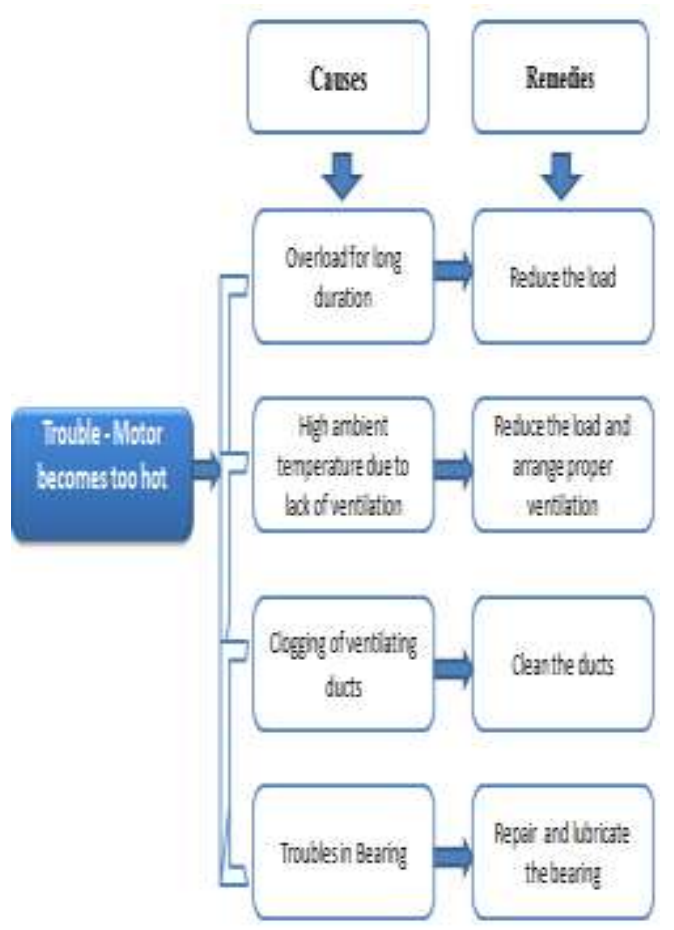

Figure 9 Motor becomes too hot trouble and their remedies

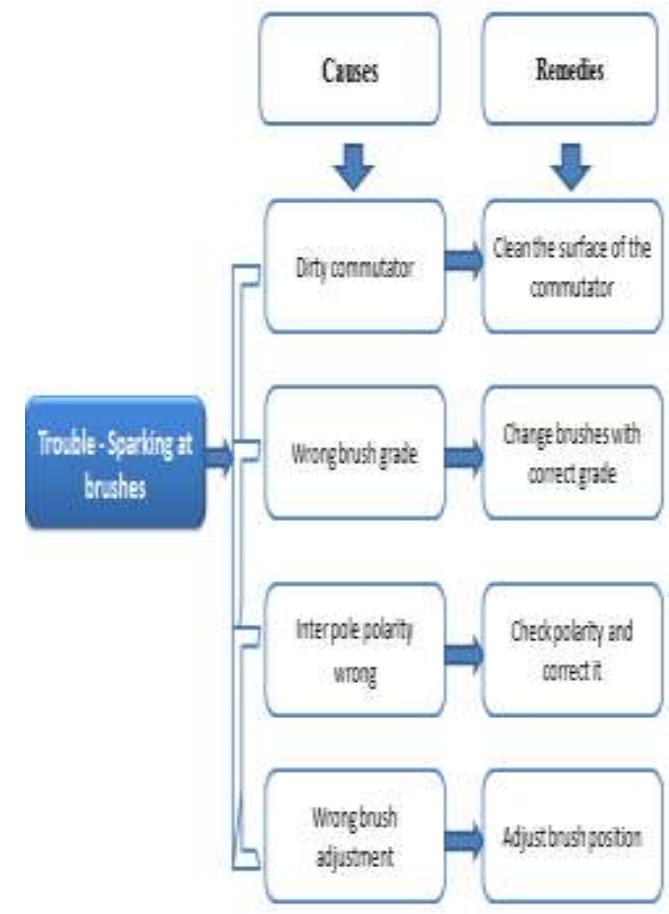

Figure 10 sparking at brushes trouble and their remedies

\section{CONCLUSION}

In this paper maintenance of DC machines were discussed in simple. Proper Maintenance of DC motor reduces unplanned downtime. Preventive maintenance can improve the motor efficiency and reduces energy consumption which will results in improved plant efficiency.

\section{ACKNOWLEDGEMENT}

We express our sincere thanks to the God, the Almighty, and Lord Jesus Christ. We express our gratitude towards our Tamil Scientist Dr. A.P.J. Abdul Kalam. We express our deep heart feelings towards His death and the people who have lost their lives in Tamil Nadu floods, 2015.

\section{REFERENCES}

[1] Basic Electrical Engineering, M.L.Anwani, Dhanpat Rai \& Co.

[2] http://www.pdma.com/pdfs/Articles/DC_Motor_Analysi s.pdf

[3] http://www.ohioelectricmotors.com/2015/07/a-generalguide-to-dc-motor-maintenance

[4] Electrical Machines -1 J. Gnanavadivel et. Al, Anuradha Publications.

[5] Testing commissioning Operation and maintenance of electrical equipment S.Rao, Khanna Publishers

[6] Brumbach, Michael.E and Clade, Jeffery. A, Indusdtrial Maintenace Thomson Delmar Learning, 2003 